\title{
Hjem, skole og kirke i min barndoms Bjerning sogn $\mathrm{i}$ 1890'erne
}

\author{
af A. H. Andersen
}

Bygmester A.H.Andersen (1881-1966) var en af de markante personligheder i Christiansfeld $\mathrm{i}$ årtierne efter Genforeningen. Han virkede som arkitekt og bygmester $\mathrm{og}$ varetog mange offentlige tillidshverv. På sine gamle dage nedskrev Andersen sine erindringer fra barndoms- og ungdomsårene. Her gengives de kapitler, som beretter om barndomshjemmet og om skolen og kirken i Bjerning sogn op mod år 1900.

\section{Indledning}

I 1938 blev bygmester Anders Hansen Andersen i Christiansfeld hædret med Dannebrogsordenen for sit mangeårige arbejde med kommunale, skolemæssige og kirkelige opgaver og for sin indsats til værn om Christiansfeld-husenes arkitektoniske værdier. To år senere kvitterede han ved at skrive sin selvbiografi. Siden blev teksten fortsat og udvidet, og 1956-58 færdiggjorde han en stor beretning om »Min fødeby Kabdrup samt optegnelser om livet omkring århundredeskiftet 1900«.

Det er en værdifuld og velskrevet beretning om livet i Bjerning sogn mellem Haderslev og Christiansfeld lige før århundredskiftet. Der fortælles om naturen og bebyggelsen, om landbrug og håndværkere, skik og brug, nationale og sociale forhold og om årets gang mellem arbejde og højtider. I det følgende gengives et par kapitler fra bogen. Forinden må det være på sin plads at præsentere forfatteren lidt nærmere.

Anders Hansen Andersen blev født på et lille husmandssted i Kabdrup i Bjerning sogn den 24.oktober 1881. Faderen Hans Andersen stammede fra Fyn. Allerede som dreng viste Anders interesse for murerhåndværket han kom i lære og tog 1903 eksamen som bygningskonstruktør ved den tekniske skole i Eutin.

I 1915 slog han sig ned i Christiansfeld som selvstændig bygmester. Her opbyggede han en stor bygmester- og arkitektforretning og bygningsmaterialhandel med op mod 25 ansatte. I de to årtier frem til krigen og i mindre grad helt frem til "pensioneringen« $i 1962$ var han gennem sine nybyggerier med til at præge byen og egnen. Det var solide og stilrene huse tilnærmet "Bedre 
Byggeskik «-stilen og med god sans for arven fra brødremenighedens klassiske huse i gule sten og med røde tegltage. Også enkelte landbrugsbygninger og nogle skoler samt Menighedshuset i Christiansfeld kom på kundelisten.

I årtier var Andersen forstander for Teknisk Skole og formand for skolekommissionen og ligningskommissionen. Han sad i byrådet, og der blev tid til flere andre kommunale tillidshverv. Sidst men ikke mindst deltog han med varmt engagement $i$ kirkens liv.

Andersen blev en af de bygmestre, som inden for sin begrænsede lokale virkekreds kom til at tegne byggeriet $\mathrm{i}$ tiden efter Genforeningen. I det følgende vil vi imidlertid slå ned på nogle andre punkter. Vi vil give ordet til hans erindringer for at høre, hvad han kan berette om sit barndomshjem og om skolens og kirkens forhold i Bjerning sogn før år 1900.

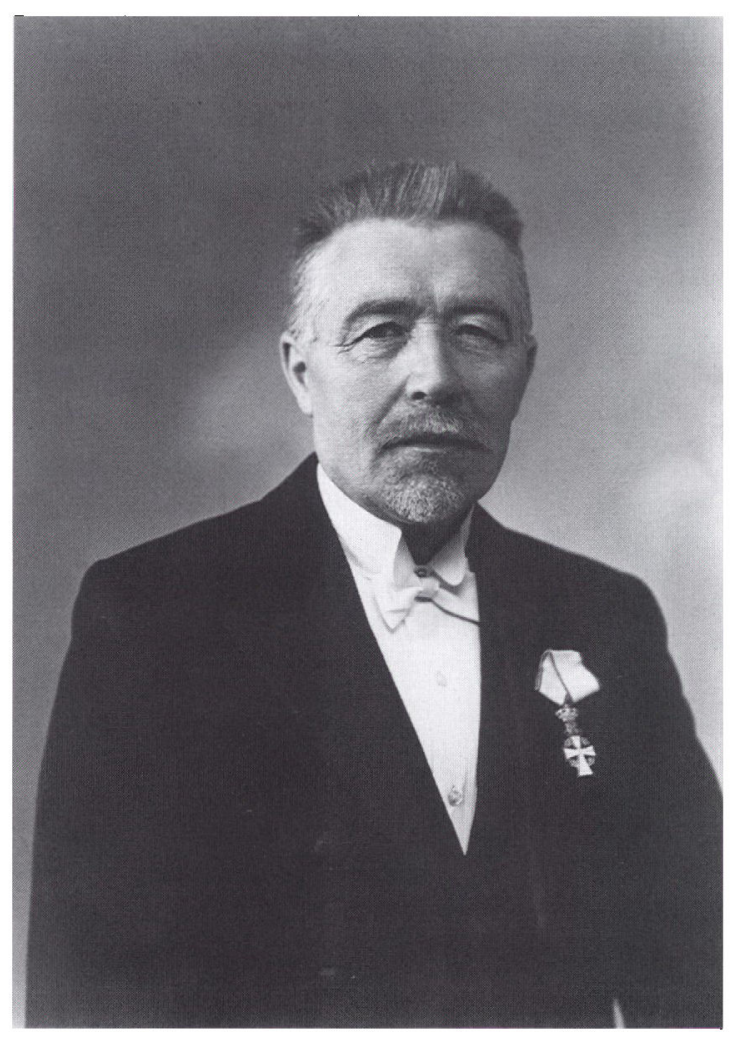

Bygmester A. H. Andersen. Christiansfeld, fotograferet $i$ 1938, umiddelhart efter at han var blevet ridder of Dannebrog. Privateje. 


\section{Hjem og forældre}

Hen på sommeren 1886 flyttede vi ind i det nye hus, til hvilket de fleste bjælker og spær, samt et og andet brugeligt materiale fra det gamle hus var flyttet med. Den åbne skorsten med arnen og under den en dejlig lille bageovn $\mathrm{i}$ tilgift var der også, og først mange år efter fik vi indmuret komfur. Foruden forstuen, køkkenet, spisekammeret, stald og lo var der 3 stuer på hver $3,40 \times 2,60 \mathrm{~m}$, og et sovekammer på $2,6 \times 1,70 \mathrm{~m}$ med plads til to faste sovepladser med en smal gang imellem dem. Her blev min eneste søster Mette født den 26.juli 1887. Kun dagligstuen og sovekammeret havde "gibset« loft, noget naboerne lagde mærke til. I stuerne var der bræddegulv, i forstue, køkken og spisekammer cementgulv, i stalden brostensgulv og i loen lergulv.

Far arbejdede for bønderne i byen de 6 dage om ugen, efter sen fyraften og om søndagen måtte han så se at få det til side ved stedets drift, som mor ikke selv kunne udføre. Bedstemor tog, så længe hun kunne, også lidt hånd $\mathrm{i}$ hanke med, så mor bedre kunne få tid til at passe sit syarbejde for fremmede. Fars dagløn hos bønderne foruden kosten var i reglen 1 mark om sommeren og helt ned til 50 penning om vinteren. Et par somre arbejdede han ved stenstrygning (med hånden) og teglbrænding på Aastrup teglværk ved Haderslev fjord.

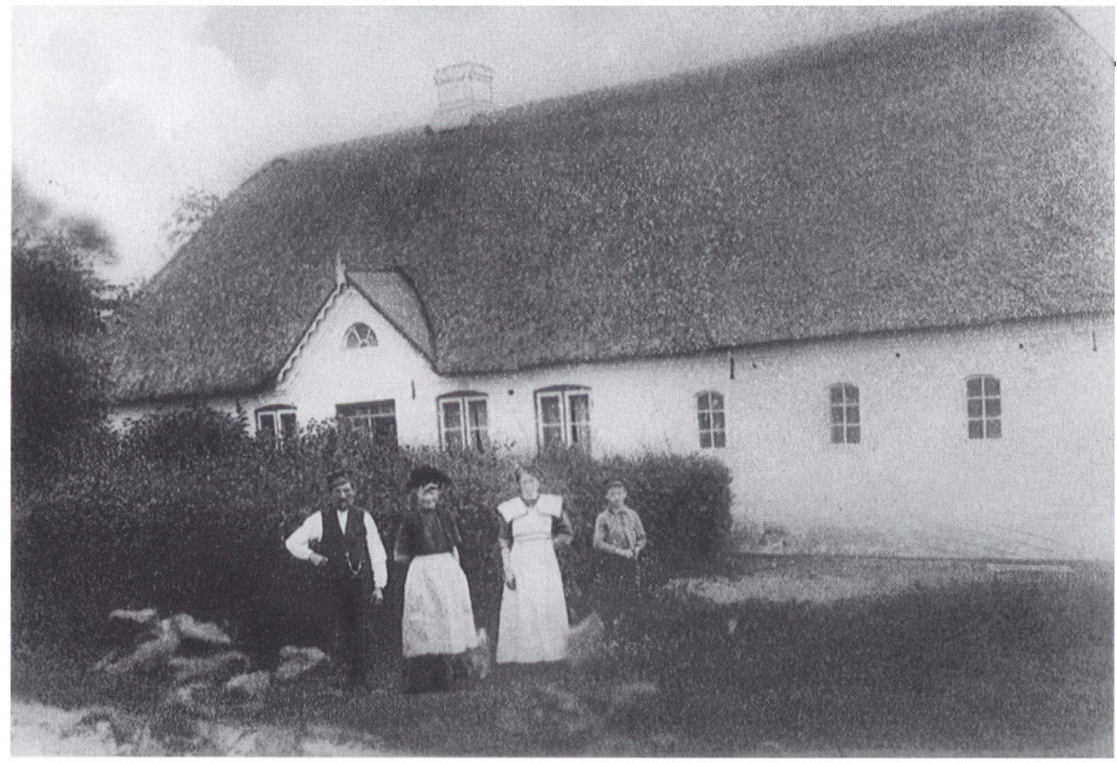

Barndomshjemmet i Kabdrup, fotograferet omkring 1912. Foran ejendommen ses A. H. Andersens foraldre Hans Andersen og Anna fodt Juhl, sosteren Mette og plejebarnet Theodor Junkner. Privateje. 
Driften af dette teglværk ophørte under den første verdenskrig og er ikke senere bleven genoptaget. Det gav nogle flere penge, men han kunne i den tid som regel også kun være hjemme fra lørdag aften til mandag morgen ved 4 tiden, da han på det tidspunkt tilfods begav sig på vej for at være klar til at kunne begynde arbejdet kl. 6 .

Omkring 1894 kom han med som brændehugger i Østerskoven, et forholdsvis vellønnet arbejde under ret frie, kammeratlige og tilfredsstillende forhold. Ved dette arbejde blev han omkring ved en halv snes år, indtil mine forældre fik samlet en 4-5 ha jord sammen, havde fảet bygget en lille lade og i 1911 fået udvidet stalden, så han kunne blive hjemme og have nok med at passe bedriften.

Mange penge havde mine forældre ikke mellem hænderne, men jeg mindes ikke, at dette nogen sinde gav anledning til misnøje eller klage. Deres redelighed $i$ alle forhold, deres nøjsomhed og tilfredshed med de givne vilkår, fars punktlighed og pligtopfyldende karakter og mors hjertegodhed og hendes forbøn har været mig et værn mod mange fristelser senere hen i livet.

Dagligstuen, der vendte mod nord, havde to torammede hvidmalede vinduer, forhængt med hvide tyllgardiner, gennem hvilke den dalende aftensol kun omkring midsommer for en kort tid lod sine stråler spille ind i stuen. Væggene i denne stue var malet med græsgrøn oliefarve. Som adgang til andre rum var der fire hvidmalede 4-fyldingsdøre, der optog en del af vægpladsen, medens der på den øvrige vagplads foruden et stueur fra midten af firserne og med renæssanceforsiringer var et sort lakeret papskilt over sovekammerdøren med indskriften »Stol paa Gud« og et par mindre, men lødige olietryksmalerier. Bræddegulvet blev skuret én gang om ugen og forøvrigt daglig fejet og sandstrøget med hvidt strandsand. Inventaret bestod af en flere »etager« høj støbejerns brændeovn med kogeindretning, købt i jernstøberiet på Naffet i Haderslev, et hjemmelavet, rødbrun malet fyrretræsbord, 4 stole samt nogle pelargonier samt en storblomstret kaktus i vinduerne. I kakkelovnen bagte mor ofte hvedebrød og andet bagværk, om vinteren stegte vi æbler på den, og engang imellem lagde mor lidt kongerøgelse ind i en af etagerne, hvorfra der udbredte sig en behagelig duft i stuen. Belysningen i den mørke årstid foregik som regel ved en petroleums-stålampe.

Middags-formaden spistes i reglen af samme fad, og enhver pillede sine kartofler ved bordet. Panden med de stegte retter blev sat på bordet på en lav trefod. Stegt flæsk var ikke nogen sjælden ret. Af fedtet blev noget hældt i fedtpotten til drøjelse af smørret til smurt brød, medens den anden del af fedtet i panden blev tilsat noget af den tykke let syrnede fløde, der var opsparet til smørproduktionen, og i denne "Duelse« tilsat lidt salt - dyppede vi kartoffelbidderne. Det smagte os dejligt. 
I køkkenet kogtes maden på arnen under den åbne 18 tommers skorsten. Under gryder og pander, der stod på en jern-trefod, blev der fyret med pindebrænde. På den årlige slagtedag og til vask kogtes vandet i større kobber- eller messingkedler, der hang $\mathrm{i}$ en stump jernkæde, der foroven var haget på en vandret liggende jernstang indmuret med begge ender i skorstensåbningens murværk. Det øvrige inventar i køkkenet bestod udover et mindre bord med en hylde underneden til gryder og pander og en skuffe til spisegrejerne af en åben tallerkenrække på væggen - "Tinterri« kaldte vi den - en kaffekværn, et tykt hakkebrædt af bøgetræ, en hakkekniv »Krumkniv«, en hårsi til sining af den nymalkede mælk, en jernmorter »Møse« til findeling af peberkærner og kanelbark, et massivt jernpressejern, et damppressejern, der blev opvarmet ved at man lagde glødende trækul ind i det, et mangelbrædt og en mangelstok til rulning af lagener og linned. På skorstensvangerne var der i mandshøjde, hvor indsnævringen af skorstenen begyndte, en hylde til svovlstikker og andre småting. Når den store flødepot var fuld, kom håndkærnen ind, og så skiftedes vi til at bearbejde fløden $\mathrm{i}$ kærnen med kærnestaven, indtil fløden havde skilt sig i større smørklumper, mindre do. »Grysninger« og kærnemælk. Skulle der bages, hvilket som regel gentog sig med et par ugers mellemrum, blev bagetruget, der bestod af en udhulet halv træstamme, bragt ind i køkkenet aftenen

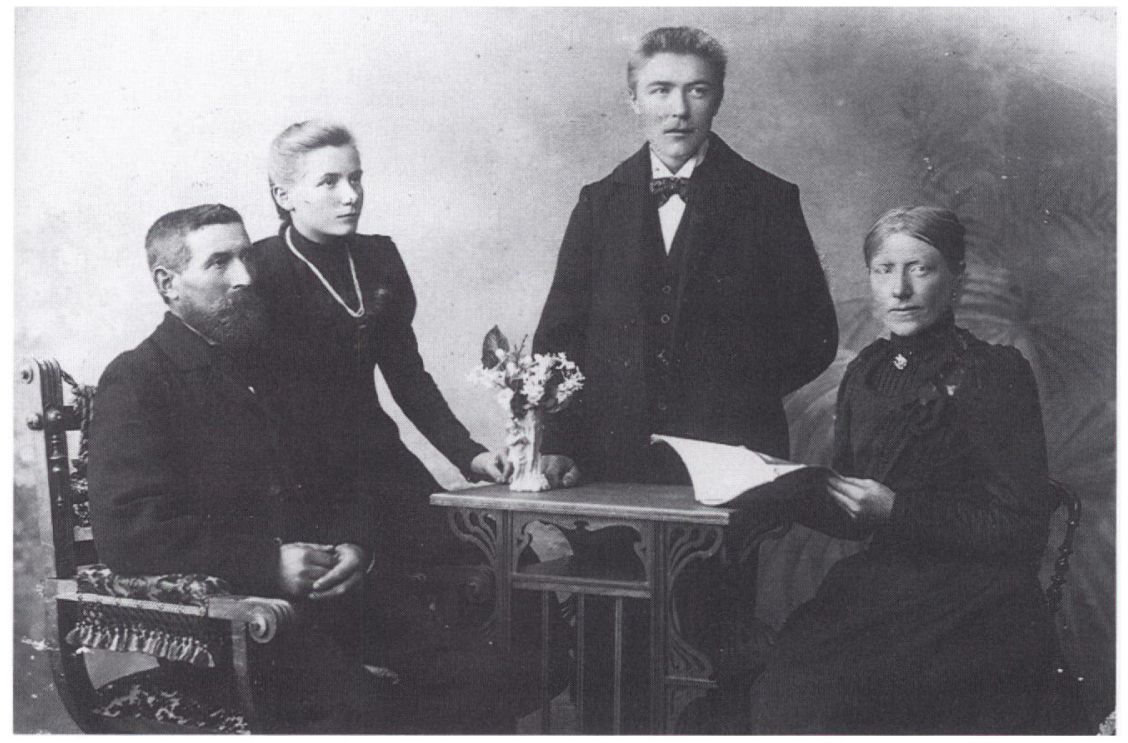

Anders Hansen Andersen er her fotograferet sammen med familien. o. 1900. Fra venstre faderen husmand Hans Andersen, Kabdrup (1854-1929), sosteren Mette og til hojre moderen Anna fodt Juhl (1856-1920). Privateje. 
før, rugmel, surdejg og vand blev blandet og æltet til dejg, og inden mor dækkede dejgen til, slog hun kors over den, vel nok med en stille bøn om Guds velsignelse af brødet.

Næste dags morgen blev ovnen fyret varm med kvas af tjørn eller andet ved, brødene blev "slået op«, ovnen renset ud og brødene sat ind i ovnen med et brædtstykke med skaft ved, en »skøssel«, og bagt. Når de forskellige dele af den slagtede gris havde ligget tilstrækkelig længe i saltkarret, blev flæskesider, skinker, bov og pølser ophængt til røgning på en stang i den åbne skorsten.

Vask af linned og klædningsstykker foregik i mangel af et vaskerum, og bortset fra kogningen i køkkenet, udendørs. Under behandlingen af vasken blev tøjet også lagt på en bænk og banket med en »Tæskel«, et fladt firkantet stykke ca. 1 tomme tyk bøgetræ, med lignende håndtag som ved et fejeblad. Til vridning af lagener efter skylningen måtte man være to.

Vandet til husholdning og vask fik vi fra en ca. $5 \mathrm{~m}$ dyb brønd i nærheden af køkkendøren. Brønden var indhegnet med et firsidet brædderækværk. Vandet blev hejst op $i$ en almindelig spand, hvis hanke blev anbragt $i$ en krog på den ene ende af en let stang "æ Kæilstang«. Det skete engang imellem, at hanken under nedsænkningen af spanden i vandet gled ud af krogen, hvorefter spanden gik til bunds, og man måtte så prøve igen at få fat $\mathrm{i}$ hanken med krogen. Da der ingen kælder var i huset, blev kærnet smør og andre ferske varer $\mathrm{i}$ den varme årstid lagt $\mathrm{i}$ en spånkurv og tildakket med friske peberrodsblade og firet ned til vandets overflade.

I de år far var med som brændehugger i Østerskoven, havde vi det godt med brændsel, idet alle skovarbejdere foruden deres lon fik nogle gode læs »kvas«, som de selv havde udsøgt sig. Når det før den tid undertiden om foråret kneb med at få brændet til at slå til, gik jeg sammen med mor eller bedstemor ind i Østerskoven og samlede en "Børren« nedfaldne grene op. Vi lagde dem i et stykke reb, og lagde os selv ned på jorden med ryggen mod brændestablen, spændte rebet over skuldrene med byrden på ryggen og bar den hjem. Til drøjelse af pindebrændet til køkkenet og til glæde for mor drev jeg undertiden lidt skovhugst $i$ de store markhegn, idet jeg samlede ikke så få »stabbe« sammen, dvs. de fra den sidste nedhugning af hegnet tilbagestående tommetykke efterhånden halvrådne kvasstumper. Der blev aldrig brugt andet brændsel end tra.

Kneb det om sommeren med græs til koen, hentede mor og jeg en sækfuld "skrub « - nogle blandede, ubestemmelige, men frodigt voksende grøntsager i skoven, eller en af os måtte ud med koen på "æ Foert«, dvs. til afgræsning af grøftekanterne på et af kommunen for en billig penge overladt vejstykke. Hindbær blev der også plukket mange af i skoven, og endelig var Østerskoven vores faste leverandør af juletræer og grankviste til kranse. 


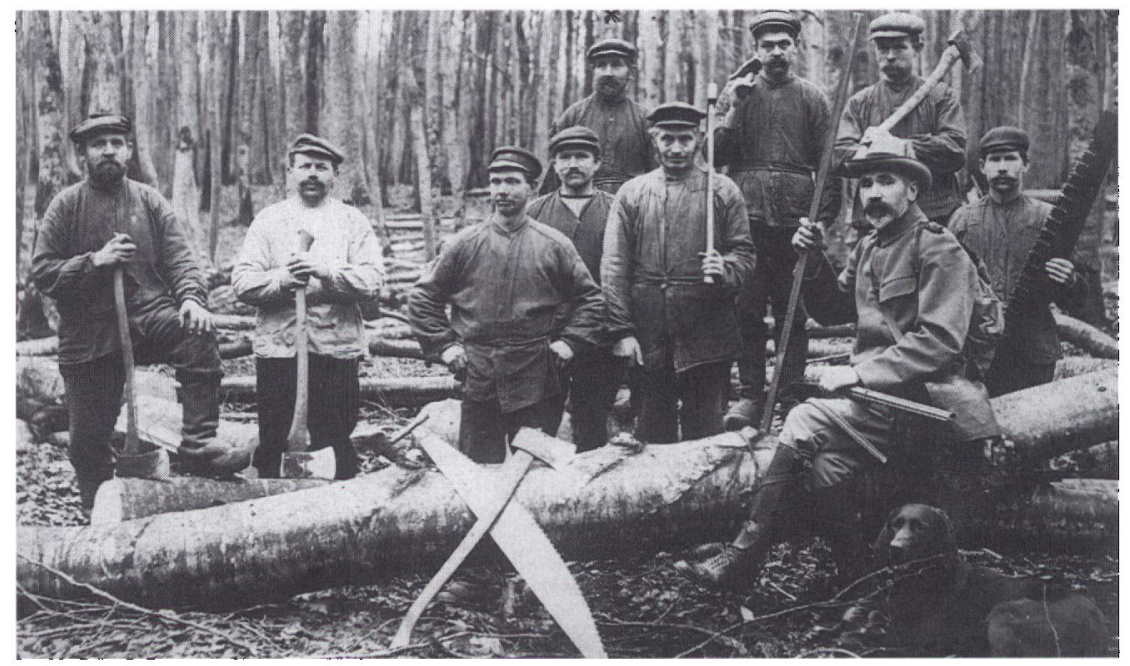

Skovarhejdere $i$ Osterskoven omkring ärhundredskiftet. Husmand Hans Andersen fra Kabdrup står yderst til venstre i bageste rakke. Privateje.

Ved pløjning og harvning af vor mark hjalp bønderne, og det modsvaredes med daglejerarbejde. Kornet blev sået med hånden, blev høstet med leen og høstakke og kornnege bar to af familien hjem på to stænger og anbragte det indtil vi fik en lade bygget - på stuehusets loft. Kornet blev tærsket med plejl og renset for avner ved håndkastning, og sædekornet blev tillige renset for ukrudtsfrø ved at ryste det $\mathrm{i}$ et rundt sold med så fine masker, at kornkærnerne ikke kunne passere igennem. Brødkornet fik vi malet og foderkornet fik vi grutnet enten i Skovbølling vindmølle, der lå ved vestsiden af hovedvej $10 \mathrm{ca}$. en $\mathrm{km}$ nord for Rørkær by, eller i Sillerup mølle. Partier i hele sække fulde fik vi en af gårdejernes vogne til at tage med til møllen, mindre partier, som kunne bæres, bar vi til møllen på skuldrene. Hvedekorn fra de opsamlede aks mellem stubbene på en af gårdmændene afhøstet hvedemark blev gemt til julebagningen og blev båret til møllen $i$ et pudevår. Første juledag måtte vi få alt det hvedebrød vi ønskede.

Min bedstemor havde i hendes stue foruden seng og en kakkelovn et dobbeltskab, et lille bord, en hjemmelavet stol med armlæn og med sædet af halmreb, et gammelt stueur, et "Tavlet" (Amagerhylde) og en kiste med buet låg. På denne kiste havde jeg min plads, når vi spillede kort sammen, f.eks. Rakker, nysgerrig Rakker, Sorte Per, Seksogtreds og Brus. Ved en sådan lejlighed, mens jeg var i konfirmationsalderen, tog hun det løfte af mig, efter hendes død engang imellem at lægge en krans på hendes grav. Som lille dreng tog hun mig 
flere gange med en tur til Haderslev, og forinden vi gik hjemad igen, gik vi ned i den daværende kælderbeværtning, Nørregade nr. 38 til Kjesten Mink, hvor vi fik kaffe. Og når det kneb for mig med at holde gåturen ud, bar hun mig et stykke vej på ryggen.

Som det var skik, gik mine forældre til alters to gange om året, søndagen efter at der et par dage i forvejen gennem skolebørn eller på anden måde var sket anmeldelse derom til degnen (førstelæreren i skolen). Under gudstjenesten ved de tre store kirkelige højtider gav far som offer til præsten 50 penning og 20 penning til degnen, indpakket $\mathrm{i}$ henholdsvis blåt og hvidt papir, der nogle dage i forvejen var bleven uddelt til hjemmene gennem skolebørnene.

I et par år, fra 1911-1913 havde mine forældre en lille rask dreng i pleje, en lille fyr, som de holdt meget af. Drengen, Theodor Jenkner, var født i sognet den 4. juli 1902, han døde pludselig efter at han var blevet stukket af et søm i foden, af stivkrampe om morgenen den 13.juli 1913 - på min søsters bryllupsdag.

I hjemmet var der afvekslende arbejde nok at hjælpe med til $i$ den tid jeg var udenfor skolen. En af de mindst interessante beskæftigelser var at passe koen på de vejstykker, som far havde lejet af kommunen; men mor var altid godt fornøjet, når jeg kom hjem med koen fra et sådant togt og hun kunne se tegn på, at dyret havde haft god tid og lejlighed til at få vommen godt fyldt. Men det, at jeg skulle have næsten hele min opmærksomhed henvendt på dette mål nogle timer $i$ træk, var ikke noget eftertragtet tidsfordriv. Af andre arbejder i hjemmet kan nævnes, at baggården skulle fejes ugentlig, der skulle renses ud i stalden, og møddingen skulle kantes op, koen skulle strigles, græsset skulle holdes borte fra broen foran huset, haven skulle graves forår og efterår, gulerødderne på marken luges og udtyndes, kvasbunken hugges til pindebrænde, brændselet drøjes med halvrådne stubber fra markhegn eller med nedfaldne grene fra Østerskoven. Mor havde også ofte brug for mig til lidt indendørs hjælp, og jeg skulle gå ærinder for hende til høkeren og til møllen. Om sommeren plukkede vi hindbær i skoven og kamilleblomster på marker, hvor sådanne fandtes. Tørrede kamilleblomster betaltes på apotekerne med 15 penning pr. pund. Hindbærrene blev solgt i Haderslev, enten i private hjem eller på torvet (Søndertorvet), og prisen var 25-30 penning pr. pund. Hjemmekærnet smør, hønsenes æg, kyllinger, hjemmerøgede flæskeskinker og bove blev solgt på samme måde. Som kontrol med at de røgede varer var trikinfri, gik der en tilsynsførende kødsynsmand omkring mellem de fremmødte på torvet og stak en lang nål ind i fiæsket, og ved derefter at holde nålen op for næsen, traf han sin afgørelse af, om varen kunne få stemplet »Trikinenfrei« eller ej.

Skønt der i 1887 blev oprettet et mejeri i sognet, varede det dog en årrække, inden mine forældre og nogle andre landmænd blev andelshavere. Mor syntes 
ikke, at vi kunne nøjes med »Futmælk« til kosten. Mandagen var torvedag i Haderslev, og jeg måtte i de sidste par år af min skoletid blive borte fra skolen mandag formiddag for at gå til Haderslev med smør og æg og forrette ærinder. De tilfældige købere på torvet var ikke alle lige tiltalende i deres manerer. Lysthavende måtte selvfølgelig have lov til at smage på smørret inden handelen blev afsluttet. Nogle brugte dertil en medbragt lille ske, medens andre uden videre tog sig en klat på tommelfingerens negl.

Sommetider gik jeg, i stedet for til Haderslev om mandagen, til Brødremenighedens by, Christiansfeld lørdag eftermiddag og solgte smørret og æggene til købmand Hellrung i Tyrstrup. Ofte havde jeg besked på bl.a. at gå ind til »æ Brøeslavde« og få et halvt pund hakket kød med hjem.

I sommerferierne var jeg hos bønderne med i arbejdet på mark og i lade for at få høsten bjerget. På de gårde, hvor jeg hjalp til, mejedes kornet endnu med le. Det var fornøjeligt at være med på høstageren - men den første høstmaskine - en aflægger - holdt $i$ begyndelsen af halvfemserne sit indtog i byen.

I min fritid byggede jeg helst småhuse af små selvlavede og soltørrede mursten eller jeg lavede løvsav- og træsnitarbejde. Som læsning har jeg flere gange læst historierne i en af Grimms eventyrbøger, bogen om Robinson Kruse samt en tysk bog, Peter Simpel, fra skolens bogsamling.

I 12 års alderen deltog jeg i et dansekursus i Thomashus, vi lærte bl.a. polka, vals, wienerkreuzpolka, mazurka, rheinlænderpolka, lancier (sekstur) og francaise.

Næsten hver sommer var vi børn sammen med far og mor på en søndagstur til fars hjemegn på Fyn, og næst efter julefesterne hører disse sommerudflugter til mine kæreste barndomserindringer. En sådan sommersøndag var vi oppe med solen og gik til fods til Haderslev. Her lå damperen "Spekulant« og i senere år "Helene« $\mathrm{i}$ havnen, parat til efter et par gange at have afgivet et kaldende signal med den dybe dampfløjtetone, at afgå kl. 6 til Assens.

Ved ankomsten dertil holdt en af mine to farbrødre med et hestekøretøj på havnepladsen og kørte os så enten til Kærum eller til Thurup, hvor der ventede os en god modtagelse og et meget veldækket bord, samt senere hen på dagen en ekstra køretur i omegnen, bl.a. over Brahesborg og Vilhelmsborg. KI. 8.30 om aftenen var vi igen efter en $2 \frac{1}{2}$ times sejltur i Haderslev, og trætte, men med en god dag bag os, spadserede vi den ene mil lange vej tilbage til hjemmet.

\section{Min barndoms skole}

Den 3. maj 1887 begyndte jeg sammen med 14 andre poder et niårigt studium i den stråtækkede Skovbølling skole, der lå $2 \frac{1}{2} \mathrm{~km}$ fra mit barndomshjem. 
Vore mødre ledsagede os den første skoledag derhen, hvor vi blev modtaget af degnen (førstelæreren) og lærerinden (hans kone) og blev beværtet ved kaffebord og med bolcher i deres lejlighed i den østre halvdel af skolebygningen. Da det var overstået, afleverede vore mødre os i underklassen (den lille skole) og tog afsked med os. Hele situationen forekom mig dog så ny og fremmed, at jeg ved afskeden bad mor om at måtte komme med hende hjem igen, hvilket hun dog med nogle kærlige ord fik mig til at opgive. I en håndtaske af farvet strå havde jeg en madpakke med til hele dagen og dertil en flaske mælk. Af værktøj havde jeg en sort skifertavle, til hvilken der var bundet en snor med en viskeklud i den anden ende, samt et »penalhus« med grifler i. Næsten hver morgen hele den første sommer fulgte mor mig godt og vel halvvejs op til skolen, op til en bakketop, hvor hun blev stående, indtil jeg havde passeret et dalstrøg og var nået frem til den næste lille bakketop i nærheden af skolen, hvorfra vi endnu engang vinkede farvel til hinanden.

Degnen »æ deen « P. W. Jacobsen var født i Ruhleben ved Pløn i Holsten den 26. maj 1844, hans kone, »æ deenkuen « Frederikke, født Grabbert i Ribe den 12.januar 1845, hun var uddannet til lærerinde i Augustenborg. Begge var dygtige, redelige og pligttro mennesker med et - for os børn at se - eksemplarisk familieliv. Selv havde de ingen børn, men derimod tre plejebørn, hvis mor fru Jacobsens søster - var død. Skønt degnen stammede fra det tysktalende Holsten, talte han et godt dansk, medens omvendt hans kone fra den gamle

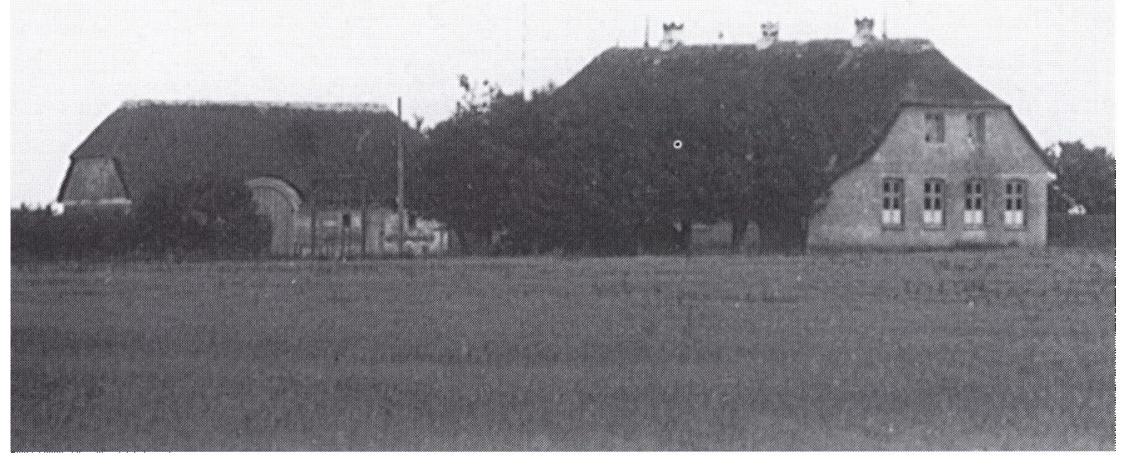

Bjerning sogns skole i Skovbolling. På pladsen mellem skolebygningen og staldladen skimtes legepladsen med klatrestranger og springbom samt den sort-hvid-røde flagstang. Udsnit af postkort for 1914. Christiansfeld kommunes lokalhistoriske arkiv. 
danske by Ribe talte et tydeligt og korrekt tysk. At de skulle være dansksindede, var der naturligvis ingen der forventede, men på den anden side behøvede man ikke at frygte for angiveri fra deres side.

Når de hos sognets dansksindede beboere deltog $i$ en privat fest, som f.eks. et bryllup eller en barnedåb, og der blev sunget nogle danske sange, som var forbudt - f.eks. Jeg er en simpel bondemand - hvor der i det sidste vers står noget om fædreland og frihed, som Preusserne nok vidste ikke gik på deres land - undlod de naturligvis også for deres egen skyld at synge med.

Skolen havde to skolestuer, nemlig underskolen »æ lilleskoel«, hvor vi forblev i fire år, og hvor vi udelukkende blev undervist af fru Jacobsen, og så overskolen »æ stoeskoel «, hvor vi derefter blev undervist i fem år af hr. Jacobsen. Skolestuerne var på $6 \times 8 \mathrm{~m}$, begge to lyse lokaler med kalkede vægge og lofter, skurede bræddegulve bestrøet med hvidt havsand.

Vi gik alle med træsko på, de fleste i træsko med træbunde og det halve af overdelen med polstret læder. Nogle bar træsko af den lettere kaliber med hele overdelen af læder, og så var der desuden en lille flok, som jeg også har prøvet at være iblandt, der havde træsko udelukkende af træ til 60 penning parret. Alt stod i forhold til forældrenes økonomiske evner.

Inventaret $\mathrm{i}$ skolestuerne bestod af et kateder, hævet et trin over gulvet, med en skuffe, i hvilket der bl.a. opbevaredes et spanskrør, endvidere en sort tavle på et stativ, en $\mathrm{i}$ fyringsperioden ikke altid vellugtende stor rund støbejerns kakkelovn fra Carlshütte Werke i Rendsborg, samt de lange sammenkoblede bænke og skoleborde med skrå bordplade, på hvilke den oprindelige fernisbehandling $\mathrm{i}$ tidens løb var slidt af, og som i stedet for af vore forgængere var bleven rigelig forsynet med navneinitialer og andre snit. Under bordpladen var der en hylde til skoletasken, tavlen, penalhuset m.m. I overskolen hang der på væggen foran os et meterhøjt farverigt billede af den unge kejser Wilhelm II i uniform og med mange ordener, og med den store og velplejede schnurrbart.

I underskolen sad pigerne på bænkene nærmest katedret, i overskolen, hvor der var en række bænke på hver side af en midtergang, sad piger og drenge på hver side af denne. Overskolen havde fælles forstue med privatlejligheden.

Udendørs var der legepladsen, et klatreværk med to cylindriske klatrestænger og et par tove, endvidere en indstillelig springbom. I min skoletid blev der tillige på legepladsen opsat en sort-hvid-rød malet flagstang, på denne blev på tysknationale festdage det tyske flag hejst. I baggården øst for skolebygningen var der en vandpost af træ, og når vi var tørstige, slog vi med den ene hånd et par slag med pumpestangen, samtidig med at vi ved med den anden hånd at holde fast om udløbstuden kunne forsyne os med godt vand. I vinkel for 
skolebygningen lå en rødkalket, stråtækket staldlade og i et par små tilbygninger et kloset til piger og et kloset samt et P.P. med en trærende til drengene.

I staldladen var der plads til et par køer og et par svin, en lo i midten og et korngulv samt brænderum. Læreren havde nemlig som organist ved kirken et stykke såkaldt degnejord, der hørte til skolen, og som degnen havde indtægterne af sålænge han var $\mathrm{i}$ embedet. Endvidere fik degnen tiende fra sognets beboere, enten i form af naturalier, som f.eks. hø, tærsket eller utærsket korn noget som vi drenge af de ældre årgange var behjæelpelig med at tage imod og bringe på plads - eller for de flestes vedkommende i penge, der for ejere af mindre ejendomme ofte kun beløb sig til nogle få penninge. Degnen i Tyrstrup har fortalt mig, at der var dem, der kun skulle betale 5 penninge i tiende, og når tiendeyderen bragte dem, blev han beværtet med kaffe og en punch.

Undervisningstimerne var i sommerhalvåret både $\mathrm{i}$ underskolen og overskolen fastsat fra 7-11 og 13-16 på ugedagene mandag, tirsdag, torsdag og fredag, på onsdag og lørdag fra 7-11, og i vinterhalvåret på de samme dage henholdsvis fra 8-12, 13-16 og 8-12.

I sommerhalvåret var der i reglen i overskolen en eller to større drenge fra mindrebemidlede, børnerige hjem, der var fæstet af en gårdejer til at hjælpe med ved at passe kreaturerne og andet forefaldende arbejde. Disse born var dispenseret for heldagsundervisningen og kom kun til skole onsdag og lørdag formiddag. Men da de i deres stilling måtte ud af sengen ved firetiden og straks med ud i marken for at hjælpe med ved malkningen af køerne, vande og flytte de tøjrede kreaturer, var de ofte for trætte og uoplagte til at deltage i undervisningen og faldt $\mathrm{i}$ søvn med hovedet hvilende på armene på bordpladen. Af menneskelige grunde lod både degnen og vi andre børn dem være i fred, og undervisningen fik de derfor ikke meget ud af.

Undervisningssproget var i mit første skoleår dels dansk, dels tysk. Vi havde også til at begynde med en dansk læsebog, der efter knap to år blev udskiftet med en tysk fibel. Thi året efter, den 18.12.1888, kom sprogforordningen, hvorefter al undervisning skulle foregå på tysk. Dermed var det danske sprog udelukket af de nordslesvigske skoler, dog med undtagelse af et par ugentlige religionstimer på dansk, som vi forøvrigt bibeholdt $\mathrm{i}$ hele min skoletid.

Da deltagelsen i de danske religionstimer var frivillig, deltog de få børn af tysksindede forældre ikke i disse, men derimod kun i de tyske religionstimer, der var obligatoriske for alle. Til brug ved undervisningen i religionstimerne havde vi både en dansk og en tysk bibelhistoriebog, og ligeledes en dansk og en tysk katekismus. Vi lærte også mange danske salmer udenad, men kun få salmer i det tyske sprog; der var jo heller ikke mange, der havde brug for salmer på dette sprog. På dage med danske religionstimer sang vi morgensang på dansk og på dage med tysk religionsundervisning på tysk. 
Skrivning foregik i de første skoleår med griffel på en sort tavle, senere gik vi over til at skrive med blæk med en spadepen, der kostede 1 penning. Gratis læremidler var der aldrig tale om. I underskolen brugte vi kun gotiske bogstaver, i overskolen lærte vi også at skrive med latinske bogstaver.

I erindringen ser jeg endnu tydeligt lærerinden, der altid var velsoigneret og i en enkel, men proper påklædning, stå ved den sorte tavle og med sin smukke håndskrift $\mathrm{og}$ med gotiske bogstaver skrive følgende sætning: "Die Soldaten verteidigen das Vaterland gegen Feinde«. Med denne sætning, som vi skulle øve os på, fik vi jo tillige en lille forsmag på den forherligelse af den tyske militærmagt, som undervisningen i tysk historie i overskolen var gennemsyret af.

Undervisningen i tysk historie "Geschichte» begyndte ved Karl den Store og hans tre sønner, for derefter at springe hele middelalderen over indtil 1640, da den store kurfyrste blev regent i provinsen Brandenburg, og så fortsattes der med en grundig og detailleret gennemgang af de efterfølgende prøjsiske regenters liv og levned og deres militære erobringer, et lidet interessant, men tværtimod uhyre trivielt fag. Hvad ragede det os, f.eks. hvorledes slagene ved Sedan, Gravelotte og andre steder i den tysk-franske krig for 25 år siden var forløbet $i$ alle enkeltheder?

Langt mere holdt vi af geografitimerne, hvor der begyndtes med en gennemgang af kortet over Slesvig-Holsten for at fortsætte med de andre elleve provinser i det daværende kongerige Prøjsen, kongerigerne Bayern, Württemberg, Sachsen og de mange andre småstater i Tyskland, de andre europæiske lande og verdensdele. Men hvordan et vesterhavsdige eller marsken så ud, langt mindre de store flader, bjergkæder og byer som vi kunne remse op på stribe, havde vi naturligvis ingen anelse om, og heller ingen mulighed for at få et onske om at få dem at se, opfyldt. Vor eneste udflugt bestod $i$, at vi en sommerdag sammen med læreren og lærerinden spadserede frem og tilbage til traktørstedet Ulvslyst ved Vesterskoven.

I sangtimerne, der var henlagt til eftermiddagens sidste undervisningstime, spillede degnen melodierne for på violin og foruden nogle få tvangsindlagte højpatriotiske tyske fædrelandssange lærte vi mange smukke og lødige folkesange med smukke melodier, af hvilke der sammen med de førnævnte fandtes 85 i vor sangbog "Deutsches Liederheft für preussische Schulen«, sange med indhold af opdragende og blivende værdi, hvis ord og toner mange endnu som gamle gerne mindes, og som man sommetider, når man ene mand $\mathrm{i}$ bilen er på farten ad landevejen, lader blande sig med motorsangen. Her skal blot nævnes det første vers af en lille sang $i$ bogen, en sang om den gamle landmands ord til sin søn, den første sang vi lærte i underskolen: 


\author{
„Üb immer Treu und Redlichkeit \\ bis an dein kühles Grab \\ und weiche keinen Finger breit \\ von Gottes Wegen ab.«
}

Melodien til denne sang brugtes endnu forst $\mathrm{i}$ trediverne som kaldesignal i den tyske radio Berlin-Königswusterhausen.

Gymnastik »Turnen « stod nok på timeplanen, men det var nok ikke degnens kæphest, for det afvikledes gerne kun med retstilling, march et par omgange på legepladsen og et "træd af!«

Forøvrigt fik vi en god undervisning $i$ alle øvrige fag, som regning og skrivning, læsning, tysk og sprog, mindre god i tegning efter geometriske fortegninger. Karaktererne bestod af tallene 1-4, af hvilke 4 var højeste karakter.

Af det tyske sprog lærte vi efterhånden det som vi havde brug for uden egentlige vanskeligheder. I underskolen havde vi til at begynde med et fag, som kaldtes Anschauung. Vi havde dertil flere vægtavler med farvetrykte billeder, f.eks. af en bondegård med gårdsplads, husdyr og landbrugsredskaber. Lærerinden pegede så f.eks. på en vogn og spurgte børnene om, hvad det var. Når så en af børnene havde svaret: "Das ist ein Wagen «, og når lærerinden havde sagt "Alle«, gentog hele holdet $\mathrm{i}$ kor dette svar. Eller hvis hun pegede på en and, blev der svaret på samme måde og således fortsattes indtil alt levende og dødt på tavlen var bleven nævnt ved navn. Lidt om ordenes køn, de tilsvarende artikler og ubestemte kendeord blev også bibragt os i disse timer. I overskolen fik vi en ret grundig undervisning i grammatikken, og ved læsning, diktat- og stilskrivning samt ved den daglige undervisning nåede vi så vidt, at vi senere hen uden vanskeligheder kunne klare os $\mathrm{i}$ andre tysktalende landsdele.

Disciplinen i skolen var der ingen vanskeligheder med. Spanskrøret lå i katederet, men blev kun sjældent brugt. Eftersidning var der heller ikke meget af. Mindre forseelser eller uartigheder blev afgjort med en lussing, et ryk i øret eller i nakkehåret. Fik en eller anden en omgang klø og forældrene eller andre fik det at vide, blev det anset for at være fortjent. Kom vi for sent og uden begrundet undskyldning, måtte vi blive stående indenfor ved døren indtil forseelsen var sonet.

Sommerferien varede fra 1 .august til 2 september. Den anden september var egentlig en fridag, men den blev dengang fejret $i$ alle tyske skoler til minde om slaget ved Sedan i den tysk-franske krig i 1870. På denne dag skulle vi møde i skolen i den første time og helst i søndagstøjet, hvilket dog ikke blev efterkommet bogstaveligt for de flestes vedkommende. Degnen gav os så et opkog af den tysk krigsførelse med den for Tyskland heldige udgang, at Frank- 
rig måtte afstå Elsass-Lothringen og desuden betale Tyskland 5 mill. mark i guld. Til indledning og slut blev der sunget et par tysk-nationale sange, og dermed havde degnen gjort sin pligt.

Den 27.januar, kejser Wilhelm den Andens fødselsdag, blev begået på lignende måde. I sin tale på denne dag fremhævede degnen navnlig kejserens gode egenskaber og hans landsfaderlige omsorg for sine undersåtter i forbindelse med det tyske riges magt og herlighed. Til slut skulle vi på denne dag synge $»$ Heil dir im Siegeskranz, Herrscher des Vaterlands« (der synges med samme melodi som melodien til den engelske nationalsang). Blandt andre obligatoriske sange var også den tyske nationalsang: "Deutschland, Deutschland über alles, über alles in der Welt « med sin kendte melodi.

I vinterhalvåret med den ene times middagspause blev de fleste børn ved skolen, i sommerhalvåret med to timers pause gik de nærmestboende børn hjem til middag. Børnene fra Kabdrup og børn fra hjem i lignende afstand fra skolen forblev der eller i nærheden af skolen i middagspausen.

I frikvartererne gik de gamle traditionelle lege år efter år deres vante gang, af hvilke flere fortrinsvis blev leget til bestemte årstider. Således blev der om foråret spillet pind og marmler i hul, hoppet $\mathrm{i}$ reb og i paradis, skåret fløjter af pilekviste og skarntyder, om sommeren blev der spillet bold, enkepar herut, skudt med flitsbue og med stenslynger, leget "put« eller »tik«, i middagspausen gik drengene til den mudrede Skovbølling dam, hvor de enten badede, sejlede ud $i$ et vandtrug eller slog »Plærrer«, eller vi legede røvere i den nærliggende lille skov. Om efteråret var det papirdragernes tid, om vinteren sloges vi med snebolde, lavede snemænd og snehuler, kørte på ståslæde, skrev gækkebreve og vers i stambøger, af hvilke lige skal nævnes et lille vers, som lidt for ofte som følge af mangel på andre ideer blev brugt: Mange glade dage, himlen skænke dig, lev foruden plage, stedse lykkelig.

Vor sidste skoledag var normalt altid fredagen før palmesøndag, da der blev afholdt konfirmation. Efter at vi var kommen tilbage til skolen fra formiddagens sidste timer hos præsten i Moltrup, holdt degnen om eftermiddagen en lille afskedstale til os. Tilbageblivende kammerater havde til denne time medbragt nogle løgskaller, som de overlod os til at gnide øjnene med. Efter talen blev der som sædvanlig på disse dage sunget: Hvo ikkun lader Herren råde, og så var vor skolegang sluttet. »Æ Præestbøen« tog nu afsked med alle øvrige børn ved at gå omkring til dem og give dem hver et stort ark af de kendte Neu-Ruppiner billeder, indeholdende bl.a. eventyr o.l. i flere billeder og med dansk tekst under hvert billede, tyske soldaterbilleder af forskellige våbenarter o.l..

Til sidst blev vi inviteret til kaffedrikning i lærerparrets lejlighed, hvor vi fik udleveret vort skolebevis (Zeugnis) med hovedkaraktererne i tysk, regning, 
skrivning og flid, samt en bemærkning om, hvorvidt vi havde nået skolens mål. Som tak for kaffen efterlod vi, som skik var, et 2, 3 eller 5 markstykke, som vi diskret anbragte under kagetallerkenen.

Det centrale $i$ hele vor skolegang var larerparrets personlighed, som jeg altid vil mindes i taknemmelighed, fordi de gennem de ni års skolegang gav os et fond af kundskaber, som satte os i stand til, ganske elementært at klare os i samfundet med andre mennesker.

Der falder heller ingen skygge på dem, fordi der vel nok var nogle børn, som undertiden i 8. og 9. skoleår følte savnet af en fremadskridende undervisning og som et handicap, at de af økonomiske og trafikale grunde ikke havde de samme muligheder for at få en videregående undervisning som børnene $\mathrm{i}$ købstæderne.

\section{Konfirmation}

Hvert år omkring 1.november kom sognepræsten fra Moltrup og Bjerning menigheder, pastor Bolten, til Bjerning skole for at orientere sig med hensyn til, hvormange børn der var gamle nok til at kunne blive udskrevet og blive konfirmeret $\mathrm{i}$ det kommende forår, eventuelt hvis der manglede noget $\mathrm{i}$ denne alder - som det var tilfældet for mit vedkommende - at få indsendt en ansøgning påtegnet med skolens erklæring til »synodeudvalget « (Synodalausschuss) om dispensation. Jeg husker godt, at jeg ikke forstod noget af det tyske ord, og henvendte mig derfor bagefter til degnen, der lovede mig, at den sag skulle han nok ordne. Dagen for konfirmationsundervisningens begyndelse blev meddelt os, præsten holdt en lille tale, der indeholdt nogle direktiver om , hvad vi skulle medbringe, og hvordan vi skulle forholde os, og samtidig lod han en lille antydning falde om, at han forventede, at dette hold konfirmander ligesom tidligere hold ville følge de gamle skikke, som havde været rådende i sognet igennem mange år.

Vi forstod godt, at det præsten tænkte på var at vi den første dag vi mødte til konfirmationsundervisning skulle medbringe en levende og særlig fed gås, en kransekage samt 4 pund svedsker af den bedste slags og aflevere disse gode gaver i præstegårdens køkken, hvor de blev modtaget af præstens døtre. Vi tre drenge havde allerede et par måneder $\mathrm{i}$ forvejen truffet aftale med en gårdejer i Aastrup parcelle om køb af en fed hvid gås til en pris af 10 mark. At den helst skulle være helt hvid, havde sin årsag $i$, at vi var enige om, at den ved afleveringen skulle være pyntet med røde silkebånd. I denne lille demonstration - som det jo var under de daværende nationalpolitiske forhold - med de rød-hvide farver var der ikke noget utraditionelt, men præsten, skønt tysk- 


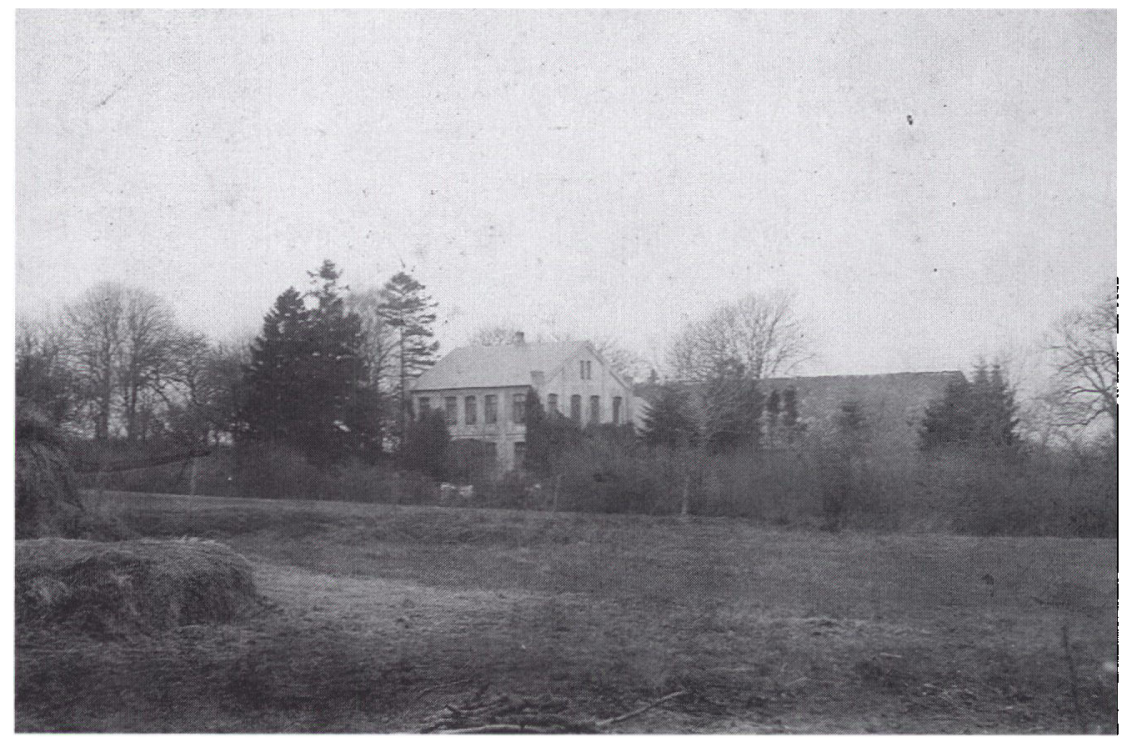

Moltrup prastegård i pastor Boltens tid. Privateje.

sindet, gjorde aldrig ophævelser i denne anledning. Pigerne, også tre ialt, sørgede for kransekagens og svedskernes tilstedeværelse og aflevering. Den forste gang vi skulle »til præst «, blev vi alle seks, tilligemed gåsen i en bærekurv, og de andre gaver omhyggeligt indpakket, kørt til Moltrup præstegård i en arbejdsfjedervogn af en af konfirmandernes fædre.

Iøvrigt gik vi hele vinteren hver tirsdag og fredag til fods frem og tilbage. Fra mit hjem og til præstegården var der $7 \mathrm{~km}$. Undervisningen varede fra $\mathrm{kl}$. 9 til 11 og var falles for børnene fra Moltrup og Bjerning. Inden børnene fra Bjerning gik tilbage til skolen, fik vi i præstens folkestue varm skummet mejerimælk, "futmælk «, til medbragt brød. Folkestuen, der var venteværelse for begge hold, var ikke ret stor, men i ventetiden var opholdet dér, når hele flokken blev samlet, ikke kedeligt. Det hændte således en dag, da præsten kom for at hente os og hilste godmorgen, at de fleste var så livligt optagne på anden måde, at præsten mindede os om, at når han kom og hilste "må I allesammen sige godmorgen!«

Pastor Johann August Hermann Bolten var født 1833 i Bünsdorf i Egernførde amt, kom 1868 fra Pelworm til Moltrup-Bjerning, blev pensioneret $1907 \mathrm{og}$ døde 1911 i Kiel, men blev begravet i Moltrup. Han var tysk uddannet og naturligvis også tysksindet, men bortset fra at det kneb for ham at finde frem til den helt rigtige udtale af nogle enkelte danske ord, var der ingen egentlige 
mangler i det danske sprog, som blev benyttet ved undervisningen. Et par ord som mig og dig blev således - som ældre generationer også må have lært det udtalt som på tysk mich og dich.

I al den tid vi gik til konfirmationsundervisning ville præsten se os i kirken hver søndag, hvilket også, bortset fra sygdom og lignende årsager, blev efterkommet. Hans prædiken var altid tydelig disponeret, og den følgende tirsdag blev vi pumpet for hvad vi havde forstået og kunne huske. Fra gang til gang fik vi opgivet flere bibelsprog, som skulle afskrives $i$ en lille bog og lares udenad. Jeg har i denne bog skrevet 168 vers. Tillige fik vi også opgivet mange salmer til udenadslæren. I skolen og under konfirmationsundervisningen lærte vi ialt ca. 70 salmer på denne måde, af den af Konsistoriet i Kiel udgivne "Evangelisk-luthersk Psalmebog for de dansktalende Menigheder i Slesvig". Denne salmebog blev benyttet indtil 1954, da den her i landet blev afløst af Den danske Salmebog.

Den sidste gang vi var hos præsten, fredagen før palmesøndag, talte han til slut meget inderlig og stærkt bevæget til os inde i konfirmandstuen. Det foltes tydeligt, at den aldrende præst bedre end vi børn vidste og forstod, at vi nu var nået til skillevejen mellem to af de mest forskellige afsnit $i$ livet. Inden vi denne dag sagde farvel, blev vi trakteret med kaffe og kage. Vist nok alle konfirmander efterlod hver en sølvmønt, en 2, 3 eller 5 mark under kagetallerkenen som gave til præsten, noget som han var godt kendt med fra tidligere hold gennem 28 år. Af præsten fik vi til afsked et lille hefte på 32 sider i sort omslag »En liden Bog for Confirmanderne«. En vejviser for unge vandringsmand ved skillevejen af W. Ziethe, præst ved Pastoralkirken i Berlin. Trykt (på dansk) og forlagt af søndagsbladet for hjemmet i Brecklum. "Til Erindring om Confirmationsdagen ved din Præst og Sjælesørger H. Bolten«. Den begyndte med: "Mit kjære Barn« og var skreven i en personlig tiltaleform og indeholdt mange gode råd og kristelige formaninger om at gå ud i livet med tak for tiden der svandt og med frimodighed til fremtiden.

Palmesøndag den 29. marts 1896 blev vi alle konfirmeret i Bjerning kirke. Det skriftsted, som jeg på denne dag fik med fra kirken, Psalme 23 vers 1, er også indtil denne dag i fuldt mål kommet mig tilgode.

Ved hjemkomsten fra kirken var der pyntet med wen ranke« omkring indgangen til huset, en af mors syelever hjalp til med opvartningen af de nærmeste familiemedlemmer og et par nabofamilier. Af gaver havde jeg jo mit konfirmationstøj, der var af hjemmegjort stof, og af gæsterne fik jeg nogle sølvpenge og nogle andre småting, deriblandt et cigarfutteral af $»$ Echt Schweineleder «. 


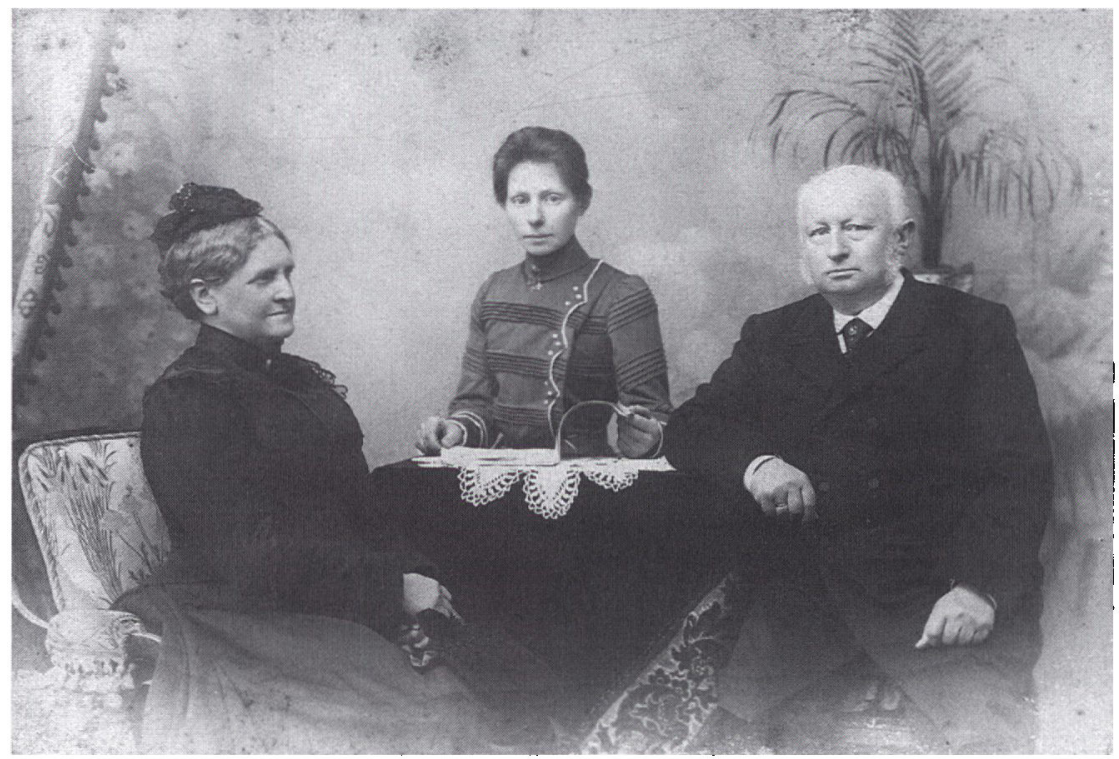

Pastor Johann August Hermann Bolten var meget afholdt som prast i Moltrup og Bjerning 1868-1907. Fra beboerne $i$ Bjerning sogn modtog han et smukt solvfad til 25-drs jubilaet i 1893. Skont tysksindet valgte familien at give prastens gravsten på Moltrup kirkegård dansk indskrift: han havde jo virket $i$ et dansktalende sogn. Prastefamilien er her fotograferet af fotograf Albr. Dose i Haderslev. Privateje.

\section{Kirkeliv}

Præsten, den før næunte pastor Bolten, var almindelig agtet og respekteret og jeg mindes kun een gang, at hans færd vakte forundring og forargelse, navnlig blandt dansksindede. Det var i juli 1905, da gdr. Jes From og hans hustru Luise i Rørkær skulle vies i Bjerning kirke. Vielsen var efter aftale med præsten fastsat til kl. 15, og til denne tid var brudeparret og bryllupsgæsterne mødt op i kirken. Præsten deltog samme dag i et synode-møde i Haderslev, hvor der inden mødets afslutning skulle finde en afstemning sted, der også havde nationalpolitisk betydning. Mødet trak dog længere ud end forudset, og præsten holdt ud for at kunne afgive sin stemme til fordel for de tyske synspunkter, hvilket havde til følge, at brudeparret og gæsterne måtte vente i $21 / 2$ time inden den kirkelige handling kunne tage sin begyndelse. Begivenhederne fik naturligvis en fyldig, men ikke blid omtale $\mathrm{i}$ aviserne.

Præsten, der for egen regning drev avlingen af præstegårdsjorden, kom altid kørende til Bjerning kirke i hestekøretøj, med sin karl som kusk på bukken, i dårligt vejr i lukket vogn. I godt vejr samledes mændene før gudstjenestens begyndelse udenfor kirken, hvor de blev stående indtil præsten kom og de $\mathrm{i}$ 
forbigående havde hilst på hinanden. Straks efter ringede »dødgraveren« med klokken, og ved første slag lettede mændene på den sorte rundpullede hat og gik ind $\mathrm{i}$ kirken, hvor de indtog en plads i stolerækkerne til højre for midtergangen, medens kvinderne havde bænket sig på venstre side. En blanding af kønnene kunne man ikke tænke sig den gang. Langs ydervæggen på mandssiden var et brædt med hattekroge, på kvindesiden var der til præstens kone en fruestol, der var kendelig på en lille afvigelse til det bedre i udstyrelsen.

Angående søndagens helligholdelse blev der i forsommeren 1904 af regeringen i Slesvig udstedt en politiforordning. Ifølge denne var på søn- og helligdage alt udendørs arbejde, såvel som alt indendørs arbejde, der forårsagede uro eller gav spektakel, forbudt. Og i gudstjenestetiden måtte gæstgiverierne ikke skænke for andre end tilrejsende personer.

Blandt kirkegængerne var der flest fra de nærmest liggende landsbyer Rørkær, Skovbølling og Errested. Fra min fødeby Kabdrup havde vi 4 km til kirken. De måtte tilbagelægges til fods, og ordinært kom de fleste kun sjældent til kirke udover ved årets store højtider, og desuden når de om foråret $\mathrm{og}$ efteråret gik til alters.

Et lille sangkor, sammensat af nogle få af skolens ældste elever - blandt hvilke jeg også var med $i$ et par år støttede fra pulpituret salmesangen. For denne lille tjeneste (eller som kompensation for slid på fodtøjet) fik vi årlig hver 3 mark. Tillige fik jeg een gang gennem degnen en henstilling fra nogle kirkegængere om at synge lidt mere piano.

Sognets beboere var ikke retningspræget i kirkelig henseende, de levede som deres forfædre havde gjort det på deres børnelærdom, og åndelige strømninger og bevægelser uden for deres egen kreds var der ingen jordbund for $\mathrm{i}$ vort sogn. Man levede nok inderst inde $i$ tro på og $\mathrm{i}$ bøn til en treenig Gud, men
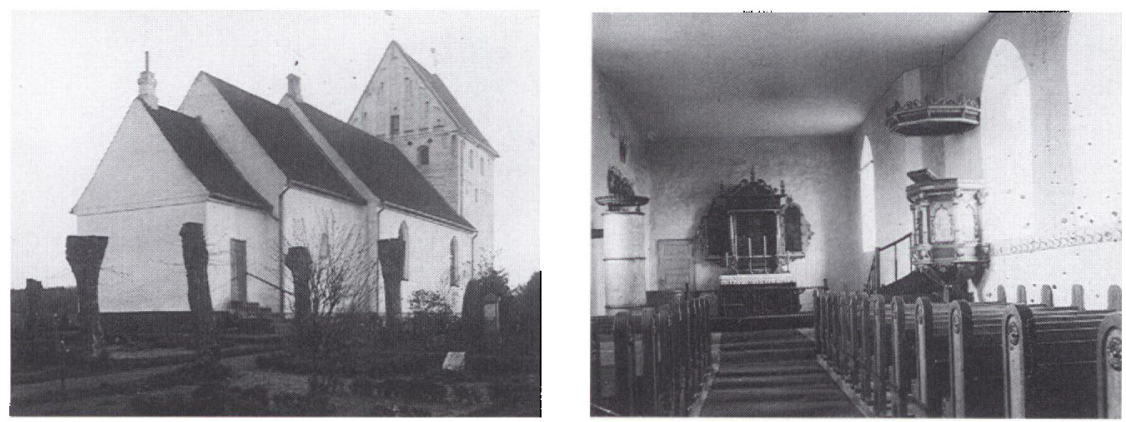

Bjerning kirke for 1914. I kirkerummet hemarker man hattekrogene pa mandssiden og kistepladerne pd venstre korvag. Historiske Samlinger. 
man drøftede aldrig sådanne problemer med hinanden. Mig bekendt fandtes der ikke noget hjem i sognet, hvor der daglig blev bedt bordbøn. Beboerne blev også så godt som uberørt af den vækkelse $\mathrm{i}$ indremissionsk retning, som $i$ halvfemserne gennem missionærers og navnlig nogle lægfolks ildnende tale $i$ offentlige møder og ved private samtaler fik tag i mange hjem i nabosognet Tyrstrup. Om denne bevægelse udtalte sognepræsten sig en gang under konfirmationsundervisningen derhen, at det ikke tilkom ustuderede mennesker at løbe rundt med en bibel under armen og forkynde fremmede lærdomme. Der var i sognet heller ikke noget frivilligt kirkeligt arbejde, som søndagsskole eller lignende.

Mange af de dengang $\mathrm{i}$ landsdelen rådende traditioner og kirkeskikke er $\mathrm{i}$ løbet af 38 år efter genforeningen i 1920 efterhånden gået af hævd. Klingpungen, der bestod af en 2-2,5 m lang rund stang med en lærredspose samt en lille bjælde ved den ene ende, blev $i$ alle kirker under afsyngelsen af den første hovedsalme rakt frem mellem rækkerne, enten af de kirkeældste på skift, eller af graveren eller som hos os skiftevis af de aldste og fremmeligste drenge $i$ skolen. Selv har jeg også $\mathrm{i}$ et års tid skiftevis med en anden dreng gået med klingpungen. Når klingpungen blev rakt frem, havde de fleste kirkegængere en lille mønt, en 1 eller en 2 penning, sjældent mere, parat til at lægge i pungen. Havde man glemt at få småpenge med, gav man sin velsignelse med et mere eller mindre dybt nik, når den passerede forbi, og i undtagelsestilfælde klarede man præsentationen med en kamufleret håndbevægelse.

Der blev på denne måde indsamlet nogle hundrede mark om året, som af de kirkeældste blev uddelt til trængende i sognet. I ældre tider, da der var mere eller mindre tvungen kirkegang, har klingpungen sikkert også skullet vække sovende kirkegængere. $\mathrm{Nu}$ i 1958 klinger klingpungen vist ingen andre steder end i et par kirker på øen Als.

Bjerning kirkegård var som kirkegårdene $\mathrm{i}$ almindelighed på den tid ikke velholdt. Græs og ukrudt blev ikke holdt $\mathrm{i}$ ave. Bortset fra gårdfolkene og andre økonomisk ligestillede blev der på den øvrige befolknings grave kun sat et simpelt sortmalet trækors, et naturligt supplement til ligkisten. Min bedstemor, der døde i 1896, fik dog et par år efter sin død en gravsten med en marmorplade, så vidt jeg husker kostede den nogle og tyve mark, men den blev bekostet af sønnen i Amerika. Kransene var beskedne hjemmebundne naturkranse af gran, buksbom eller kristtjørn med nogle enkelte have- eller stueblomster. Skulle det være noget mere fint, havde man jo perlekransene. At bestille en naturkrans hos en gartner var for den javne befolkning noget ukendt.

Altergang i kirken afholdtes på nogle søndage om foråret og efteråret, og vel nok de fleste bosiddende gik til alters disse to gange om året. Forinden 
skulle man helst senest om fredagen forud - i reglen gennem skolebørnene meddele sin deltagelse til degnen, der så lod antallet af de anmeldte gå videre til præsten pr. bud. Telefon var der dengang ingen der havde, min forste telefonsamtale havde jeg som ung konstruktør i 1903.

At præsten forud for altergangen ønskede at få tallet på nadvergæsterne havde sin årsag i den endnu gældende bestemmelse i kirkeordinantsen, at der kun må uddeles indviet brød og vin. Man søgte at undgå at komme i den situation, at det indviede brød og den indviede vin slap op, så der enten måtte foretages indvielse to eller flere gange, eller at der måtte gribes til den udvej at uddele uindviede nadverelementer som Herrens legeme og blod.

En halv time for gudstjenestens begyndelse indfandt altergæsterne sig i kirken, præsten holdt skriftetalen, hvorefter gæsterne gik op til alterskranken og knælende modtog absolutionen. Efter at de ovrige kirkegængere efter gudstjenestens slutning alle havde forladt kirken, gik altergæsterne igen op til alteret og modtog under dæmpede orgeltoner af melodien til salmen "Nu skal du, min sjæl dig smykke« - brød og vin, det sidste af et fællesbæger, der i præstens hænder blev drejet lidt under vandringen fra gæst til gæst.

Altergangsgæsterne var altid klædt i sort, og forinden man gik op til alteret tog mændene overfrakken og kvinderne hovedbeklædningen af.

Ritualet under selve gudstjenesten var iøvrigt i det store og hele det samme som i nutiden. Nogle enkelte gloser, som f.eks. "annammer den apostolske velsignelse«, har jo fået en anden ordlyd.

Til de tre store højtider blev der gennem skolebørnene uddelt blå og hvide offersedler til alle hjem, henholdsvis fra præsten og degnen, for at erindre folk om, at der på første helligdag var offergang i kirken. For en husmand betød det $\mathrm{i}$ penge 50 penning til præsten og 20 penning til degnen.

Når en kone første gang efter en fødsel igen kom i kirke (holdt sin kirkegang), gik hun efter prædiken sammen med sin ledsager (kirkekonen) op og knælede ved altret, mens præsten bad en bøn og lyste velsignelsen. Ved denne lejlighed blev der også lagt et offer i offerskålen.

Hvis nogen gav alterlys til kirken, som regel var det kun mænd i kirkens bestyrelse (kirkeældste) der gjorde det, fik de til tak og minde derom deres navn malet med hvide bogstaver på et sort blikskjold i tysk stil og af tysk massefabrikat, af hvilke der dengang i de fleste kirker hang flere eller færre på en væg $i$ koret.

Ved dødsfald ønskede man den afdødes nærmeste familie "glæde for sorg«. Når døden var indtrådt, blev »liget lagt på strå « i nogle dage, dvs. at det blev liggende $\mathrm{i}$ sengen på et lagen på stråunderlaget, indtil snedkeren, der lavede kisten efter mål og med håndkraft, havde fået den færdig og liget kunne lægges i kisten. Denne var som regel sortmalet. 
Nogle dage før begravelsesdagen - der som regel fandt sted en uges tid efter dødsfaldet - blev der sendt en budkone »Bojkuen« ud til den afdødes nærmeste venner og naboer for at indbyde dem til samvær efter begravelsen. Stående ret op lige indenfor stuedøren afleverede hun en tillært remse, der begyndte med en hilsen fra den afdødes slægtninge og en meddelelse om, at N.N. var indgået til den evige hvile og fortsatte med at nævne navnene på dem i huset, som man ønskede at se som deltagere i sørgefesten, for tilsidst at slutte med en anmodning til de indbudte om at medbringe spiseredskaber. Så aflagde budkonen det alvorlige ansigtsudtryk og man fortsatte en lille stund med en drøftelse af begivenheden $i$ et mindre højtideligt sprog.

På begravelsesdagen kom degnen og "sang ud«, dvs. der blev sunget en salme og bedt en bøn i den stue, hvor kisten med liget stod, hvorefter låget blev lagt på kisten af snedkeren og kisten båret ud til ligvognen af 6 mænd, der var særlig indbudt til »at bære«. Ligvognen var sortmalet med englehoveder på baldakinen og forspændt med to heste med eller uden sorte dækkener. Den benyttede ligvogn ejedes af snedkeren i Fjelstrup, og prisen for at låne den rettede sig efter, om man selv ville lægge heste og kusk til, samt om forspandet skulle være med sorte dækkener eller uden disse. Til mindrebemidlede (småfolk) var en af gårdejerne altid rede til at stille en fjederkassevogn med kusk og forspand til rådighed. Ligfølget, med de gående nærmest efter ligvognen og de kørende i den bageste ende, var klædt i deres bedste sorte tøj, mændene havde så godt som alle deres cylinderhat på, og hvis der var nogle få, der ikke ejede en sådan, så havde de dog en sort, rundpuldet stiv hat. På vejen ud for alle huse, som ligfærden kom forbi, var der strøet blomster eller grønt.

I kirken holdt præsten ligtalen, som han fik ekstra betaling for. For laveste takst holdt han talen stående i kordøren, og for en højere takst gik han på stolen. Nysgerrige mennesker stillede gerne det spørgsmål til dem, der havde været med: „Va han å’e stol«. Degn og graver fik også ekstra betaling for deres medvirken.

Gravstederne hørte til ejendommen, og der betaltes ingen afgift til kirken. Der tilkom graveren en afgift for hvert gravsted, et ganske minimalt beløb, som han hentede hos gravstedejerne hvert år mellem jul og nytår.

Til slut skal endnu nævnes nogle af de mest brugte hovedsalmer ved årets forskellige højtider. Nytår: »Kom Hjerte, tag dit Regnebrædt«. Fasten:»Jesus, dine dybe Vunder«. Skærtorsdag: »O, Ansigt højt forhånet«. Langfredag:»Hil dig Frelser og Forsoner«. Påskedag: »Som den gyldne Sol frembryder«. Pinse: »O Helligånd, kom til os ned«. Julen: »I denne søde Juletid«. Dåb: »Enhver, som tror bliver døbt«. Konfirmation: »Lad denne Dag, o Gud vor Gud«. Altergang: »Af Dybsens Nød mit Råb til dig«. Ægtevielse: »Det er så yndigt at følges ad«. Begravelse: »Tænk når engang den Tåge«. 


\section{NOTER OG HENVISNINGER}

Nærværende uddrag af A.H. Andersens erindringer »Min fødeby Kabdrup« er gengivet efter det duplikerede manuskript $i$ privateje. Der er foretaget enkelte mindre udeladelser og sproglige justeringer (ved Lars N. Henningsen).

Supplerende materiale, herunder levnedsløb, avisudklip, manuskripter samt bygningstegninger findes i Christiansfeld kommunes lokalhistoriske arkiv (U. 162 og A. 271).

Se endvidere Christiansfeld kommuneatlas. Udgivet af Miljøministeriet, Planstyrelsen, i samarbejde med Christiansfeld kommune, 1992, s. 14. 